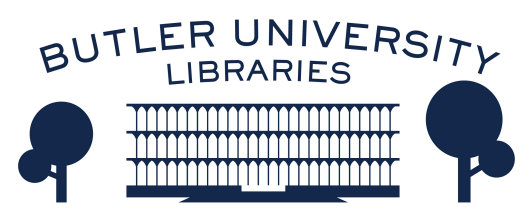

Journal of Hindu-Christian Studies

\title{
Book Review: "Hindu God, Christian God. How Reason Helps Break Down the Boundaries between Religions"
}

Bradley Malkovsky

Follow this and additional works at: https://digitalcommons.butler.edu/jhcs

Part of the Religion Commons

\section{Recommended Citation}

Malkovsky, Bradley (2002) "Book Review: "Hindu God, Christian God. How Reason Helps Break Down the Boundaries between Religions"," Journal of Hindu-Christian Studies: Vol. 15, Article 19.

Available at: https://doi.org/10.7825/2164-6279.1286

The Journal of Hindu-Christian Studies is a publication of the Society for Hindu-Christian Studies. The digital version is made available by Digital Commons @ Butler University. For questions about the Journal or the Society, please contact cbauman@butler.edu. For more information about Digital Commons @ Butler University, please contact digitalscholarship@butler.edu. 
emphasis on Advaita Vedanta's mayavadin non-dualism as the representative Hindu theological system. As Abhinavagupta states in his dedicatory verse, "We praise Siva, who manifests the differentiated universe as the prima facie argument, and then leads it back to unity as the established conclusion."

Second, it is a sophisticated and erudite exercise in cross-cultural methodology in opposition to skeptical relativism and in support of the achievement of a universal intelligibility of differing philosophies. If these philosophies are intelligible, a reflective choice may be made among as to which is more coherent, and thus a greater achievement of truth. Relying on, and advancing beyond, the work of Bernard Lonergan and David Tracey, Lawrence concludes that the "relativization of relativism" . . . suggests that universally valid knowledge and values are approachable asymptotically."

Third, Lawrence convincingly concurs with Utpaladeva's and Abhinavagupta's transcendental/ontological argumentation for God's existence. He presents an extensive and sympathetic comparison of this argument with the Thomistic argument of the Jesuit Bernard Lonergan [1904-84] who states, "The existence of God, then, is known as the conclusion to an argument and, while such arguments are many, all of them, I believe, are included in the following general form. If the real is completely intelligible, God exists. But the real is completely intelligible. Therefore, God exists." Lawrence sees a similarity of argumentation in Abhinavagupta, "There are all worldly behaviors by means of this triad of Saktis. By the triad of Saktis of the Blessed One there is the manifestation of [limited individuals such as] Caitra, Maitra, etc., who are the perceivers, rememberers, and [semantically exclusive] conceptualizers [vikalpayitr]. For it is [actually] $\mathrm{He}$ who cognizes, remembers and conceptualizes in this and that form. As it has been said by the precepter: 'Although the establishment of objects is concealed by the individual soul as delimited by the vital breaths and psychophysical complex [puryastaka] --neverthelessthat [establishment] is [actually] accomplished in the Supreme Self' . . . If this is not accepted, nothing can appear. Thus is the undesirable consequence. However, [this world] does appear. Therefore, this [the Saiva understanding of the Lord with His Saktis] must necessarily be accepted. Thus there is the avoidance of the undesirable consequence."

Fourth, it is a welcome example of the hermeneutics of charity in action. This hermeneutics takes the thought of a major thinker and treats it with utmost seriousness, avoiding the reductionism of the many varieties of the hermeneutics of suspicion that are so prevalent today. These hermeneutics of suspicion are tempted not to take seriously the carefully-reasoned thought of the other. Lawrence's splendid work will help move the work of the Society of HinduChristian Studies to a new level.

Daniel P. Sheridan Saint Joseph's College of Maine

\section{Hindu God, Christian God. How Reason Helps Break Down the Boundaries between Religions. Francis X. Clooney. Oxford University Press, 2001, viii +209 pp.}

FRANCIS CLOONEY'S latest work (see previously Theology After Vedanta, Seeing Through Texts, Hindu Wisdom for All
God's Children) continues the comparative theology task of attentive inter-textual reading. The author sets about to show the 
many ways theologians past (Hindu) and present (usually Christian, the exception being Roberto de Nobili) have employed reason in articulating the intelligibility and plausibility of their own doctrinal position while refuting the errors and inconsistencies of alternative views. Clooney finds enough similarity in the way reason is employed by both Hindu and Christian thinkers and sufficient intelligibility in their theologizing for him to advocate serious theological conversation between them and even a mutual accountability in the articulation of doctrine and its supporting arguments. Clooney's explicit goal is to "unsettle the religious and theological boundaries that have neatly divided theologians according to their religions. I argue that whether theologians are Hindu or Christian they are still colleagues at least intellectually accountable to one another."(27) He adds, "I do not presuppose that the Christian versions of positions considered here are superior to the Hindu alternatives. Other theologians may wish to make the case for a judgement of that sort, but they will first have to join an interreligious, comparative, dialogical, and confessional conversation in which some of their peers, to whom they are answerable, are Hindu."(28) The methodological outcome will be a constructive theology, faithful to its home tradition, but widened, deepened and challenged through the critique and enrichment offered by the other and at the same time a theology that strives to become more comprehensible to the outsider in its articulations.

The book is comprised of six chapters. After arguing in the first chapter the need to broaden Christian theological reflection to include the work of those outside one's own tradition Clooney gets down to the business of meticulous theological comparison in chapters two to five. Each of these four middle chapters takes up one theological theme that is addressed first by a Christian theologian of the twentieth century and then by more than one - and sometimes several Hindu thinkers and even an occasional
Buddhist. The topic for chapter two is the cosmological argument for God's existence, which is here propounded by the Christian thinker Richard Swinburne. Clooney then marshals as a response the arguments of two Naiyayikas (Annambhatta, Jayanta Bhatta), a Saiva Siddhantin (Arul Nandi), a Buddhist (Dharmakirti), a Mimamsaka (Kumarila Bhatta), and a Visistadvaita Vedantin (Vedanta Desika) and shows the strategies they employ in reasoning for or against a theistic worldview. Clooney's breadth in drawing on such a wide array of positions is truly impressive and instructive.

Chapter three places Hans Urs von Balthasar in dialogue with such Vaishnaivites as Ramanuja, Sudarsana Suri and Vedanta Desika and the Saivite theologians Sripati Pandita Acarya and Arul Nandi on the issue of God's character and activity. Who is the true God? Is it Visnu, Siva, or the God of Christians? Or are they all the same God?

Chapter four takes up perhaps the thorniest of theological issues in the HinduChristian encounter, namely God's embodiment. In comparing the incarnation theology of the German Catholic theologian Karl Rahner with the views of Arul Nandi, Vedanta Desika, Bhatta Narayana Kantha, Ramanuja, Nampillai and others, Clooney notes how for all these thinkers the various understandings of divine embodiment, whether Hindu or Christian, are elucidated in a very reasonable fashion. These theologies, moreover, despite their clear differences in regard to the possibility of divine suffering and of the degree of divine involvement in matter, all profess the merciful "commitment of God to the human race" (124). I was most struck in this chapter by Nampillai's awe before the gracious mystery of divine self-debasement: Lord Narayana, the creator of the world, has taken on the very real, perishable, honorless, and soiled form of a boar. (119-120)

Chapter five is given to a discussion of the place of revelation in giving guidance for sorting out truth claims. We see here 
that reason must be constrained and guided by revelation, both in thinking properly about doctrines founded on revelation and also about the teachings of others that are not founded on such. Clooney notes the overlapping but also divergent views of revelation and its relation to scripture propounded by Karl Barth, Kumarila, Salika Natha, Ramanuja, Arul Nandi, Nanjiyar and others. It is only in such a book as Hindu God, Christian God that one learns that "Barth thinks like a Hindu" or that there are "Hindu Barthians". (17)

In his final chapter (six) the author concludes that in today's new pluralistic situation theologians have everything to gain by overcoming attitudes of superiority and condescension and opening themselves to the reasoned doctrines and arguments of alien theological traditions. One learns to rethink an initial position in light of the insights of others. Ideally one's knowledge of God is thereby expanded. It is also expected that one might take an apologetic stance in defending the truth of one's tradition and in persuading others of that truth.

Clooney's book is aimed at a primarily Christian audience (188), hence the greater attention to Hindu theological positions than to Christian ones. As he draws on both famous and lesser-known Hindu thinkers in his wide-ranging and penetrating summaries Clooney succeeds in unveiling the richness and complexities of Hindu thought, which too often has been lumped together as monolithic and summarily dismissed by Christians who have not read deeply or at all in the relevant literature.

I nevertheless would have liked to see greater attention given to Christian theological positions that directly address Hindu doctrine, especially in the chapter on divine embodiment. Rahner, the sole Christian voice on this topic, is basically unaware of Hindu teachings on incarnation, whereas such modern stalwarts as Josef Neuner, Geoffrey Parrinder, Richard De Smet, Jacques Dupuis, Diana Eck and others have taken very interesting, useful and different avenues of approach to the comparative question of divine embodiment, and they have done so on the basis of a deep immersion in both Christian and Hindu traditions.

One final thought: the subtitle of Hindu God, Christian God is How Reason Helps Break Down the Boundaries between Religions. But one could just as well conclude that reason serves as much to divide as unite. At the end, I think, we are left with reason's inconclusiveness. It is clear that when left to itself reason need not normally lead to any particular religious conviction. The force of tradition is strong, and it is rare that reason might sway one to shift allegiances or to revise one's dearly held convictions about the nature of deity, divine presence or divine involvement in human life. What is most important are the convictions one starts with. Reason argues for the intelligibility, plausibility and even superiority of one's inherited belief over that of others. Clooney recognizes this; he says that even when "reasoning is meticulous" it is "also deeply influenced by prior religious dispositions." (49) He notes how religious faith "is deeply influential even regarding the reasonable arguments that take place. Both the Hindu and Christian proponents and antagonists of the induction of God's existence know where acceptance of the induction leads and what could be gained or lost by denying it. Even in the course of the most reasoned arguments they are anticipating where the arguments might lead and accordingly steer the arguments toward conclusions they already firmly believe. . . Faith does not render argument useless, but it does affect its tenor and purposes."(59) Indeed, in his final chapter Clooney acknowledges his Christian faith and why he prefers some Hindu doctrines over others. It is precisely because he is already a Christian theologian that he sides with Hindu theistic theologians rather than with Buddhists, Mimamsa theologians, and nondualist Vedanta theologians. (178) He prefers the 
Vaisnava rather than Saiva view of divine embodiment, because the former more closely resembles "the Christian theological position with which I grew up and which I have found reasonable and satisfying over the years."(178)

But if there is to be inter-religious theological conversation at all, whether to further the ends of apologetic or of mutual illumination, it is true that reason must be its presupposition and mainstay. Francis Clooney has written the definitive work on this in the context of the Hindu-Christian encounter. The book is therefore indispensable reading for any serious study on the topic.

Bradley Malkovsky

University of Notre Dame

\section{Missionaries, Rebellion and Proto-Nationalism: James Long of Bengal 1814-87. Geoffrey A. Oddie. Surrey: Curzon Press, 1999, $261 \mathrm{pp}$.}

THIS BOOK has an intriguing title. What, you may ask, could James Long, as a British Christian missionary in 19th century colonial Bengal, have to do constructively with "rebellion" and "proto-nationalism"? From this point of view, the heart of the book lies in chapters 7 and 8, which deal with the (in)famous indigo controversy and its aftermath of the 1860s (incidentally, there should be no apostrophe, as there is repeatedly in this rather poorly copyedited book, before the "s" (viz. "1860's") when periods are mentioned in this way). Long, together with a number of other missionaries of the Protestant church, played a major role in exposing the persistent and brutal exploitation of the local cultivators or ryots by European planters (and many Indian zemindars) in the production of indigo. The point, as I see it, of Oddie's characteristically well-researched though somewhat pedestrian treatment is that by his eventual if brief imprisonment in the ryots' cause, Long not only rebelled with important symbolic undertones against many government officials' and other colonials' expectations of how a missionary should behave, but also became himself something of a rallying point for "proto-nationalist" sentiment among westernised Indians. However, since this last point is not contextualised in any detail in terms of what might pass for the "proto-nationalism" of the times, justification for part of the book's title at any rate must be pronounced to be wanting.

By the time of his trial, Long had come a long way from his privileged origins in Brandon in southern Ireland in the early 19th century. After an excellent education, rich in the classical and biblical languages, and a conversion to evangelicalism, Long arrived in Calcutta, the centre of the British raj, in 1840. He was based there until 1872 . During these 30 odd years, as Oddie points out in other chapters of his informative book, Long became proficient in the knowledge of Bengali, and equally important, focused his missionary endeavours on seeking to study and improve the lot of rural Bengalis, with special emphasis on education in the vernacular (in contrast, say to an Alexander Duff - whom Long greatly admired - who concentrated on educating the children of more westernised Bengalis in English in the urban context of Calcutta). In this, Long was something of a pioneer, and this emphasis alone is well worth the careful study Oddie has made of him.

Also, both interesting and significant, was Long's preoccupation with what Oddie calls sociological issues, viz. Bengali 